\title{
Self-renewal of pluripotent embryonic stem cells is mediated via activation of STAT3
}

\author{
Hitoshi Niwa, ${ }^{1,2}$ Tom Burdon, ${ }^{1}$ Ian Chambers, and Austin Smith ${ }^{3}$ \\ Centre for Genome Research, University of Edinburgh, Edinburgh EH9 3JQ, UK
}

\begin{abstract}
The propagation of embryonic stem (ES) cells in an undifferentiated pluripotent state is dependent on leukemia inhibitory factor (LIF) or related cytokines. These factors act through receptor complexes containing the signal transducer gp130. The downstream mechanisms that lead to ES cell self-renewal have not been delineated, however. In this study, chimeric receptors were introduced into ES cells. Biochemical and functional studies of transfected cells demonstrated a requirement for engagement and activation of the latent trancription factor STAT3. Detailed mutational analyses unexpectedly revealed that the four STAT3 docking sites in gp130 are not functionally equivalent. The role of STAT3 was then investigated using the dominant interfering mutant, STAT 3F. ES cells that expressed this molecule constitutively could not be isolated. An episomal supertransfection strategy was therefore used to enable the consequences of STAT3F expression to be examined. In addition, an inducible STAT3F transgene was generated. In both cases, expression of STAT3F in ES cells growing in the presence of LIF specifically abrogated self-renewal and promoted differentiation. These complementary approaches establish that STAT3 plays a central role in the maintenance of the pluripotential stem cell phenotype This contrasts with the involvement of STAT3 in the induction of differentiation in somatic cell types. Cell type-specific interpretation of STAT3 activation thus appears to be pivotal to the diverse developmental effects of the LIF family of cytokines. Identification of STAT3 as a key transcriptional determinant of ES cell self-renewal represents a first step in the molecular characterization of pluripotency.
\end{abstract}

[Key Words: Leukemia inhibitory factor (LIF); cytokine receptor; signaling; ES cells; tetracycline; episome]

Received December 1, 1997; revised version accepted A pril 23, 1998.

Embryonic stem (ES) cells are pluripotent cell lines derived by culture of preimplantation mouse embryos (Evans and Kaufman 1981; M artin 1981; Brook and Gardner 1997). At present, ES cells are the only nontransformed mammalian stem cells that can be continuously propagated in vitro. ES cell self-renewal is sustained by the cytokine leukemia inhibitory factor (LIF) (Smith and Hooper 1987; Smith et al. 1988; Williams et al. 1988). The effect of LIF is to inhibit differentiation and support proliferation of undifferentiated stem cells. However, the mechanisms underlying the maintenance of pluripotency during proliferative expansion remain elusive. We are attempting to define those si gnaling processes downstream of the LIF receptor complex that direct ES cell self-renewal. Elucidation of these principles will provide a molecular model for stem cell regulation in mammals. Insights provided by such a model should al so be di rectly

\footnotetext{
${ }^{1}$ These authors contributed equal ly to this work.

${ }^{2}$ Present address: Department of Nutrition and Physiological Chemistry, Osaka University Medical School, 2-2 Yamadoaka, Suita, Osaka 565, Japan.

${ }^{3}$ Corresponding author.

E-MAIL austin.smith@ed.ac.uk; FAX 441316670164.
}

applicable to the extension of ES cell technology to nonmouse species.

The actions of LIF are mediated via heterodimerization of two members of the class I cytokine receptors, the low-affinity LIF receptor (LIF-R) and gp130 (Gearing et al. 1991; Gearing and Bruce 1992; Davis et al. 1993). The LIF-related cytokines, oncostatin M (OSM), cardiotrophin (CT-1), and ciliary neurotrophic factor (CNTF), act through the same receptor complex (in the case of CNTF, additionally including the CNTF-R $\alpha$ subunit) and can similarly sustain ES cell self-renewal (Conover et al . 1993; Rose et al. 1994; Wolf et al. 1994; Y oshida et al. 1994; Pennica et al . 1995b). Furthermore, ES cells can also be derived and maintained using a combination of interleukin-6 and soluble interleukin-6 receptor (IL-6/ slL-6R) (N ichols et al. 1994; Y oshida et al. 1994). In this case, signaling is initiated via formation of gp130 homodimers without involvement of LIF-R (Murakami et al. 1993; Y oshida et al. 1994). Signals that emanate from gp130 are therefore sufficient for self-renewal .

gp130 mediates cellular responses to IL-6 and IL-11 in addition to the LIF-related cytokines (Kishimoto et al. 1994). All of these factors exert pleiotropic effects on 
diverse cell types in vitro and in vivo. In addition to ES cell self-renewal, stimulation of gp130 receptor complexes causes differentiation and growth inhibition in M 1 myel oid leukemic cells (Tomida et al. 1984), induction of acute phase gene expression in hepatocytes (Baumann and Wong 1989), cholinergic differentiation of sympathetic neurons (Y amamori et al. 1989), survival of motor neurons (Li et al. 1995), proliferative and hypertrophic responses in cardiomyocytes (Hirota et al. 1995; Pennica et al . 1995a; Y oshida et al. 1996), and astrocyte differentiation of neuroepithelial progenitors (Bonni et al. 1997; Koblar et al. 1998).

Signal ing processes downstream of gp130 are complex and are not yet fully characterized. Ligand-induced dimerization of the receptors (Davis et al. 1993; Murakami et al. 1993) leads to phosphorylation and activation of associated JAK tyrosine kinases ( $\mathrm{N}$ arazaki et al. 1994; Stahl et al. 1994). The cytoplasmic domain of gp130 contains several tyrosine residues that are phosphorylated by the activated JAKs. These phosphotyrosine residues then interact with $\mathrm{SH} 2$ domain containing proteins that in turn themselves become targets for JAKS and possibly other nonreceptor tyrosine kinases. Consequences include activation of the Ras mitogen-activated protein (M AP) kinase (ERK) signal ing cascade (Boul ton et al. 1994; Yin and Yang 1994; Sheng et al. 1997) and of the ST AT factors ST AT 1 and ST AT 3 (Lutticken et al. 1994; Stahl et al. 1995). STAT proteins are latent transcription factors that upon phosphorylation, dimerize and translocate to the nucleus where they activate target gene transcription (for review, see Ihle 1996). In myel oid leukemic M 1 cells, activation of STAT3 appears to be the main effector of the differentiation response to IL-6 or LIF (M inami et al. 1996; N akajima et al. 1996). STAT 3 activation has also been adduced to mediate CNTF or LIFinduced differentiation of neuroepithelial precursors into astrocytes (Bonni et al. 1997).

In this study we have examined the receptor requirements for self-renewal signaling in ES cells and determined a critical contribution of STAT3 activation. In contrast to its role in somatic cells, activated STAT3 acts to suppress differentiation in ES cells.

\section{Results}

Granulocyte col ony-stimulating factor receptor can signal ES cell self-renewal

Granulocyte col ony-stimulating factor receptor (G-CSF$R$ ) is a class I cytokine receptor that is evolutionarily related to gp130 and LIF-R (Gearing et al. 1991; Chambers et al. 1997). G-CSF-R is not present in ES cells. To begin delineating the signal ing requirements for ES cell propagation, the capacity of these related receptors to sustain self-renewal was compared directly.

G-CSF-R undergoes ligand-induced homodimerization to produce an active signaling complex. G-CSF responsiveness can therefore be conferred on cytoplasmic domains of heterol ogous receptors through construction of appropriate fusions. CDNAs encoding full-length G-
CSF-R CDN A and fusions between the extracellular portion of G-CSF-R and the transmembrane and cytoplasmic region of gp130 or LIF-R were cloned into the expression vector pPCAGIZ. Plasmids were introduced into LIF-R-deficient ES cells to eliminate the contribution of autocrine LIF signal ing (Rathjen et al. 1990) from subsequent analyses. In this and all other experiments, ES cells were grown without feeder layers (Smith 1991). Transfectants were selected and expanded in the presence of IL-6/sIL-6R, acting through endogenous gp130, to avoid any sel ective pressure for adaptation to the introduced receptor.

Stable transfectants were then plated at clonal density in the absence of cytokine or presence of IL-6/SIL-6R or G-CSF. The number of stem cell colonies generated was scored after 6 days. The data in Figure 1A show that the G-CSF-R/gp130 chimeric receptor sustained stem cell propagation in response to G-CSF. This result is an-

A

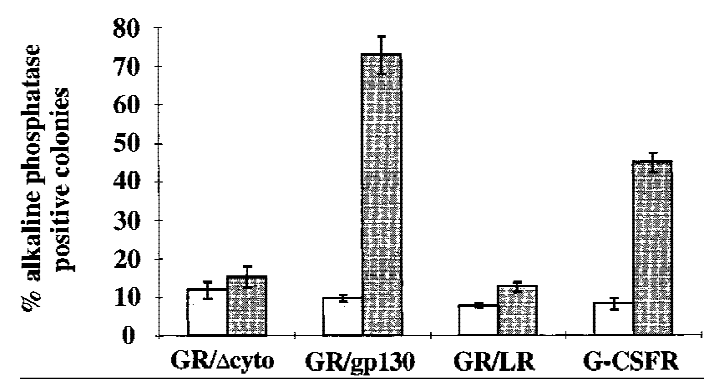

B

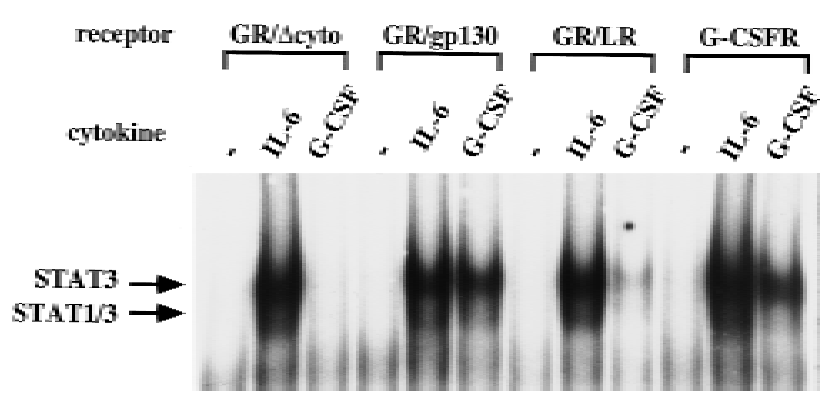

Figure 1. ES cell self-renewal and induction of STAT DNAbinding activity mediated by G-CSF-R wild-type, truncated, and chimeric cytokine receptors. (A) Efficiency of clonal stem cell renewal in response to G-CSF measured by formation of alkaline phosphatase-positive colonies. (Light gray bars) -G-CSF; (dark gray bars) +G-CSF. Data are mean \pm S.E.M. of triplicate determinations on single representative clones normalized to response to IL-6/sIL-6R. (B) Induction of STAT DN A binding by IL-6/sIL-6R and G-CSF determined by electophoretic mobilityshift assay. Cells were untreated or stimulated for $30 \mathrm{~min}$ with IL-6/sIL-6R or G-CSF (30 ng/ml). Nuclear extracts were prepared and assayed for SIE binding. N ote the absence of detectable STAT1/STAT3 heterodimer complex on stimulation of full-length G-CSF-R. 
ti cipated from previous findings on the capacity of gp130 homodimers to signal self-renewal (Yoshida et al. 1994). The G-CSF-R/LIF-R chimera did not support formation of stem cell colonies despite higher levels of cell surface expression measured by radi oligand binding (not shown). This is in line with previ ous reports that homodimerization of the LIF-R cytoplasmic domain results in quantitatively (Baumann et al. 1994a; Stahl et al. 1995) and qual itatively (Stahl et al. 1995) diminished activation of downstream pathways compared with LIF-R/gp130 heterodimerization or gp130 homodimerization. However, ES cells transfected with G-CSF-R did form stem cell colonies in response to G-CSF-R though with lower efficiency than cells expressing the G-CSF-R/gp130 chimera. This somewhat surprising finding corroborates similar data reported recently (Starr et al. 1997). Propagation of the G-CSF-R transfectants remained factor dependent, and the cells differentiated normally when deprived of cytokine.

The finding that G-CSF-R is competent to maintain the stem cell phenotype suggests that the signaling interactions essential for ES cell self-renewal are preserved between gp130 and G-CSF-R. Conserved features in the intracellular domains of these two receptors are not readily identifiable because of extensive sequence divergence. However, G-CSF-R contains a putative STAT binding site and is thought to signal primarily through activation of STAT 3 (Shimozaki et al. 1997). Electrophoretic mobility-shift assays were performed to determine the induction of nuclear ST AT DNA-binding activity by G-CSF in the various ES cell transfectants. Significant STAT3 activation was evident in ES cells transfected with expression vectors for the G-CSF-R/gp130 chimera or the full-length G-CSF-R. In contrast, ES cells expressing the G-CSF-R/LIF-R chimera showed only weak induction of STAT3 DNA-binding activity in response to G-CSF (Fig. 1B). Antibody supershift experiments (not shown) confirmed that the DNA-binding complex consisted predominantly of STAT 3 homodimers with a minor component of STAT3/STAT1 heterodimer as described previously in ES cells and other systems (Hocke et al. 1995; Stahl et al. 1995; Starr et al. 1997). These observations pointed to a potentially critical role for STAT3 activation in mediation of the self-renewal signal.

\section{STAT3 docking sites on gp130 are required to signal ES cell self-renewal}

The cytopl asmic domain of mouse gp130 contains seven tyrosine residues. Four of these have been identified as phosphorylation-dependent sites of interaction with ST AT 3 (Stahl et al. 1995). Substitution of these tyrosine residues with phenylalanine in the context of the G-CSF$\mathrm{R} / \mathrm{gp130}$ chimera was therefore used to determine their significance for self-renewal signaling. The modified chimeric receptor expression constructs were introduced into DO27 ES cells. These cells are LIF-deficient because of targeted deletion of both gene copies and, in addition, carry a $\beta$-gal actosi dase reporter integrated into one al lele of the O ct-4 gene (C. Dani , I. Chambers, S. Johnstone, M.
Robertson, B. Ebrahimi-Chahardahcherik, M. Saito, T. Taga, M. Li, T. Burdon, J. Nichols, and A.G. Smith, in prep.). This reporter is expressed only in undifferentiated ES cells (Mountford et al. 1994). Self-renewal was assayed both by measuring $\beta$-gal actosidase activity in medium density cultures (Fig. 2B) and by scoring formation of alkaline phosphatase positive colonies at clonal density (Fig. 2C). Three independent transfectant clones were analyzed for each receptor. The data summarized in Figure 2 demonstrate that the presence of ST AT 3 docking sites is essential for stem cell propagation.

The intact gp130 cytopl asmic domain mediated a clear induction of SIE DNA-binding activity (Fig. 2D). Mutation of individual docking sites had no appreciable effect. However, mutation of all four sites eliminated both the self-renewal signal and the induction of STAT3 DNAbinding activity. Radioligand binding established that cell surface expression was not limiting for any of the receptors (not shown). To confirm that other signaling pathways are not impaired by mutation of the STAT3 docking sites, we examined activation of the ERK cascade. ERK activation requires receptor phosphorylation on tyrosine 118 by JAK kinases and recruitment of SHP2 (Stahl et al. 1995; Fukada et al. 1996). Figure 2E shows that the basal level of constitutive ERK activity was significantly enhanced by stimulation of chimeric receptors in all transfectants tested. In particular, the two receptors, Y 265/275F and Y 126-275F, which gave reduced activation of STAT 3 and cannot signal self-renewal, mediated normal and heightened levels of ERK activation, respectively. Therefore, there is no general compromise in the signaling capacity of these molecules.

Interestingly, this data also indicates that the ST AT3 sites in gp130 may not be equivalent in vivo. Specifically, mutation of the two adjacent carboxy-terminal STAT3 binding sites (Y265 and Y275) abolished selfrenewal signaling, whereas mutation of the two-membrane proximal sites had little effect. This difference correlated with the lower induction of STAT3 DNA-binding activity and the specific reduction in STAT3 phosphorylation relative to ERK phosphorylation (Figs. 2D,E) (see Discussion). Self-renewal thus appears to require an appreciable level of STAT3 activation.

Inhibition of STAT3 activation blocks self-renewal and promotes differentiation

The above findings indicated that STAT 3 may play a key role in ES cell signaling. To assess directly the requirement for STAT3 activation in ES cell self-renewal, we expl oited a dominant interfering mutant form of STAT 3, STAT 3F. In this mutant (Minami et al. 1996), the tyrosine residue at amino acid position 705 is mutated to phenylal anine. Phosphorylation of Tyr705 is required for dimerization and nuclear translocation. When expressed at high levels, STAT3F has been shown to block the activation of endogenous STAT3 in various cell types, possibly by titrating out receptor docking sites (Fukada et al. 1996; Minami et al. 1996; Nakajima et al. 1996; Bonni et al. 1997; Ihara et al. 1997). 
A

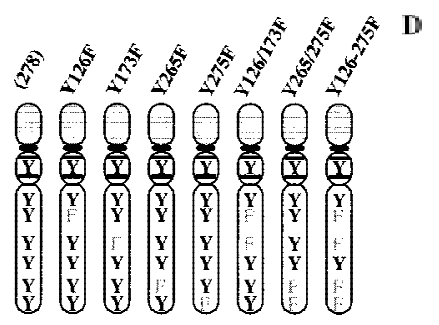

B

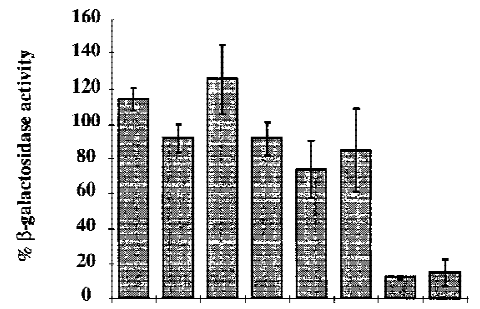

C

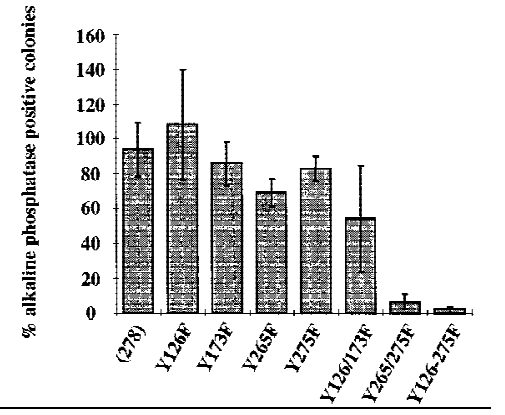

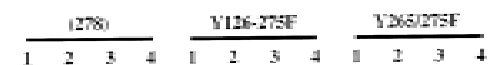

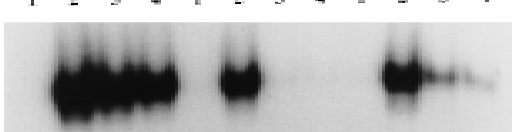

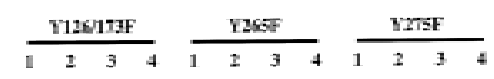

E
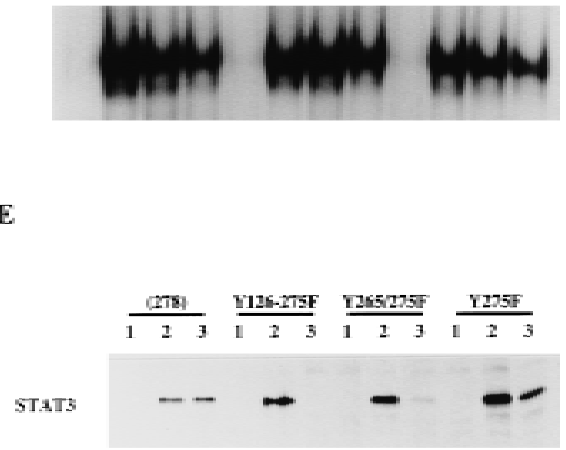

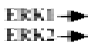

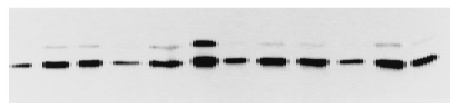

Figure 2. Effect of mutating STAT3 interaction sites in gp130 on ES cell self-renewal and induction of STAT 3 DN A-binding activity. (A) Schematic of the various chimeric receptors indicating the tyrosine-phenylalanine substitutions introduced into the wild-type (278) gp130 cytoplasmic domain. N umbering commences with the first residue of the 278-amino-acid intracellular domain of mouse gp130. The phenylalanine $(F)$ for tyrosine $(Y)$ substitutions in the four STAT3 docking sites are indicated. The additional three tyrosines do not interact with STAT3 (Stahl et al. 1995). (B) Stem cell renewal mediated by chimeric receptors in response to G-CSF measured by $\beta$-galactosidase expression from the Oct-4 locus. Data are mean \pm S.E.M. for duplicate determinations on three independent clones normalized relative to response to IL-6/sIL-6R. (C) Efficiency of clonal stem cell renewal mediated by chimeric receptors in response to G-CSF measured by formation of alkaline phosphatase positive colonies. Data are mean \pm S.E.M. for duplicate assays on three independent clones normalized relative to response to IL-6/sI L-6R. (D) Electrophoretic mobility-shift assay of induced STAT3 DNA binding. Transfected clones were left untreated (lane 1) or stimulated for 30

min with IL-6/sIL-6R (lane 2) or with G-CSF at $30 \mathrm{ng} / \mathrm{ml}$ (lane 3) or $3 \mathrm{ng} / \mathrm{ml}$ (lane 4). N uclear extracts were assayed for SIE binding. (E) Immunobl ot of STAT 3 and ERK phosphorylation induced by G-CSF stimulation of chimeric receptors. Transfected clones were left untreated (lane 1) or were stimulated for 20 min with IL-6/sl L-6R (lane 2) or with G-CSF (lane 3). Immunoblots of cell Iysates were probed sequentially with antibodies specific for the active phosphorylated forms of ERK and STAT3.

Using conventional transfection approaches, we were unable to recover ES cell transfectants showing stable high-level expression of STAT3F. In parallel experiments, however, transfection of the LIF-independent embryonal carcinoma cell line P19 yielded multiple expressing clones. This suggested that blockade of STAT3 activation in ES cells specifically resulted in cell death, growth arrest, or differentiation. An alternative transfection and expression strategy was therefore adopted to enable characterization of the consequences of STAT3F expression. The approach, termed supertransfection, relies on expression of polyoma virus large T protein by the recipient ES cells and its interaction with a polyoma origin of replication present in the transfected DNA. This results in efficient episomal propagation of incoming plasmid (Gassmann et al . 1995). We have devel oped this system for efficent CDNA expression in ES cells $(H$. N iwa, I. Chambers, L. Forrester, M. Gassmann, and A.G. Smith, in prep.). The process yields at least 100-fold more stable transfectants than conventional transfection protocols. A second important advantage of episomal supertransfection is that the unpredictable effects of chromosomal integration are avoided, with the result that the level of expression is both stable and relatively uniform (H. N iwa, I. Chambers, L. Forrester, M. Gassmann, and A.G. Smith, in prep.).
The STAT 3F mutant CDNA was introduced into the supertransfection vector pHPCAG. The wild-type STAT3 coding sequence was also introduced, in both sense and antisense orientations. The three constructs were el ectroporated into M G1.19 cells that harbor a large $\mathrm{T}$ expression plasmid and can be supertransfected with constructs containing the polyoma origin (Gassmann et al. 1995). Supertransfectants were isolated by selection in hygromycin B for 8 days in the presence of LIF. Colonies were fixed, stained with Leishman's reagent, counted, and scored for the presence of stem cells and differentiated cells. More than $95 \%$ of colonies obtained following supertransfection with control or wild-type ST AT 3 vector were stem cell colonies (Fig. 3A). A modest increase in the proportion of differentiated colonies was obtained with the antisense construct. The STAT 3F vector, however, yielded predominantly differentiated colonies. A decrease in total number of colonies was al so observed after supertransfection with STAT3F. This may reflect an early onset of differentiation that would produce very small clones that would not be scored. Alternatively, very high levels of STAT3F expression may also be toxic, though this has not been reported in other cell types. Morphologically, the differentiated STAT3F colonies closely resembled the differentiated colonies generated on culture of ES cells in the absence of LIF (Fig. 
A

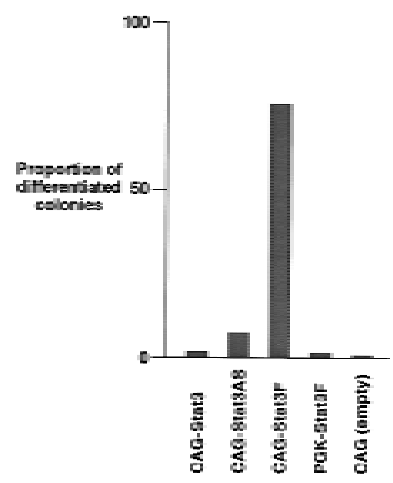

$\mathrm{C}$

(i)

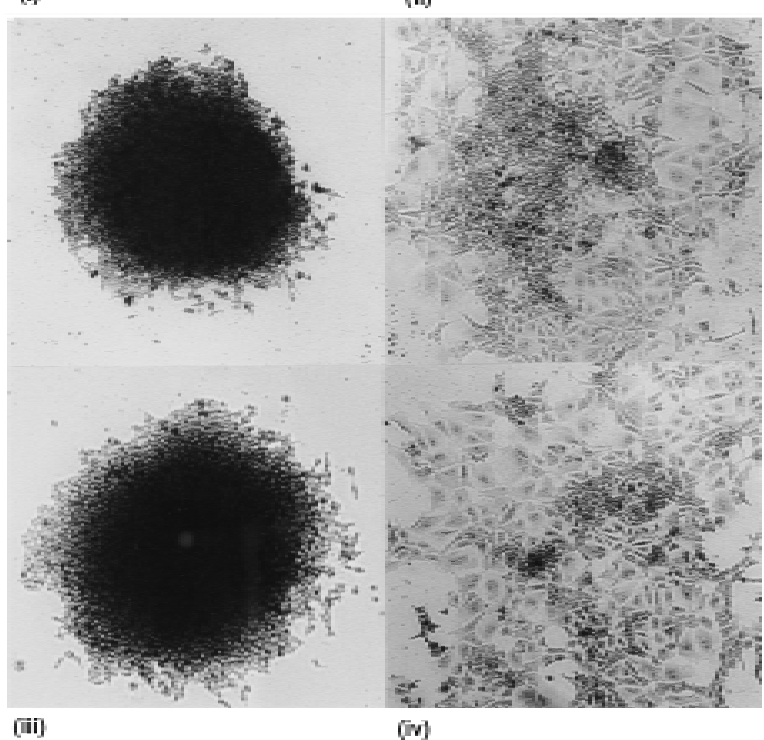

Figure 3. Induction of differentiation by expression of STAT 3F in MG1.19 ES cells. (A) Proportion of differentiated colonies in LIF-supplemented medium resulting from supertransfection of STAT3, antisense STAT3, and STAT3F expression vectors. Colonies were fixed and stained with Leishman's reagent after 8 days of selection, and the numbers of stem cell colonies and differentiated colonies were scored. (B) M arker gene expression in STAT3F supertransfectants. Expression of marker genes in pools of MG1.19 cells supertransfected with STAT3 (lane 1), STAT3 antisense (lane 2), and STAT 3F (lane 3) expression vectors. Total RNA was prepared after 8 days of selection in LIFsupplemented medium, and $5-\mu \mathrm{g}$ aliquots were analyzed by filter hybridization with $\beta$-globin, Rex-1, H19, and G3PDH probes. The $\beta$-globin probe detects all transgene mRN A species generated from pHPCAG, including an alternatively spliced product from the antisense contruct. (C) Photomicrographs of representative colonies 8 days after supertransfection with (i) STAT3, (ii) STAT3F, and (iii) empty expression vectors and selection in the presence of LIF, or (iv) induction of differentiation by culture in the absence of LIF for 8 days.

3C). Various other CDNAs have been expressed in ES cells using this system, with little or no effect on formation of stem cell colonies (data not shown). This suggested that the effect on differentiation was specifically attributable to expression of ST AT 3F.

The differentiation induced by expression of ST AT3F was examined further by expression analysis of the marker genes rex 1 and $\mathrm{H} 19$. Rex-1 mRN A, which is specifically expressed in undifferentiated stem cells, was down-regulated in STAT3F supertransfectants. In contrast, H19 RNA, which is found at low levels in stem cells but is up-regulated during differentiation, was increased (Fig. 3B). A similar pattern of gene regulation is observed during differentiation of ES cells induced by withdrawal of LIF. These data confirm that the morphological differentiation triggered by STAT 3F is accompanied by reprogramming of gene expression.

STAT 3F was also expressed from the mouse phosphoglycerate kinase (pgk-1) promoter in the episomal vector pHPPGK. This vector gives at least 10 -fold lower expression than pHPCAG (H. Niwa, I. Chambers, L. Forrester, M. Gassmann, and A.G. Smith, in prep.). In this case, there was no significant effect on either colony number or differentiation status of M G1.19 supertransfectants. A relatively high level of expression of the dominant interfering mutant therefore appears necessary to block selfrenewal.

Effect of STAT3F on self-renewal is suppressed by coexpression of STAT3

To test whether the induction of differentiation by expression of STAT3F was due to an inhibition of endogenous STAT 3 activity, we attempted to rescue the stem cell phenotype by coexpression of wild-type STAT 3 and also of STAT 1 and STAT4. A STAT3F expression vector carrying a blasticidin resistance marker was cosupertransfected into M G1.19 cells with episomal constructs for expression of wild-type STATs and hygromycin resistance. Cosupertransfectants were isol ated in medium containing both $20 \mu \mathrm{g} / \mathrm{ml}$ blasticidin S and $80 \mu \mathrm{g} / \mathrm{ml}$ of hygromycin B. The numbers of stem cell and differentiated col onies were scored after 8 days. As shown in Figure 4, only coexpression of wild-type STAT3 restored self-renewal in the presence of STAT3F. Transfection with STAT 1 or STAT 4 constructs al one had no effect on self-renewal in the absence of STAT3F (not shown) and did not alter differentiation induced by STAT3F. In the case of supertransfection with the CAG promoter STAT 1 construct, the total number of colonies (stem plus differentiated) recovered was reduced, but the relative proportion of stem cell colonies versus differentiated cells was unaltered. This occurred in both the presence and absence of coexpression of STAT3F and suggests that high-level expression of STAT 1 may be toxic to ES cells. By using the mouse PGK-1 promoter to drive lower levels of expression (H. N iwa, I. Chambers, L. Forrester, M. Gassmann, and A.G. Smith, in prep.), comparable numbers of col onies were recovered on transfection with the STAT1 as with the other constructs. In this case, again only the ST AT 3 construct showed any restoration of stem cell colonies, although to a lower degree than with the high-expression CAG vector (not shown). These data indicate that STAT3 has a specific function in ES cells that cannot be compensated by STAT1 or STAT4 (see Discussion). 


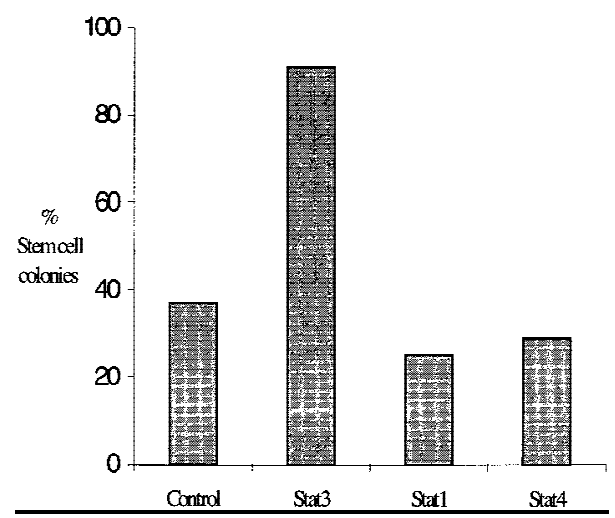

Figure 4. Cosupertransfection of STAT $3 F$ with wild-type STAT expression vectors. Proportions of undifferentiated stem cell colonies generated after cosupertransfection of MG1.19 ES cells with $10 \mu \mathrm{g}$ of pBPCAGGS-STAT $3 F$ plus $10 \mu \mathrm{g}$ of pHPCAG vector containing stuffer (control), STAT3, STAT1, or STAT4 inserts. After 8 days of selection with $80 \mu \mathrm{g} / \mathrm{ml}$ of hygromycin B plus $20 \mu \mathrm{g} / \mathrm{ml}$ of blasticidin S, colonies were fixed and stained with Leishman's reagent.

\section{Generation of an inducible STAT3F transgene} integration in ES cells

The effect of STAT3F expression on endogenous ST AT 3 activity could not be monitored directly in undifferentiated ES cells because ES cells expressing appreciable STAT 3F constitutively could not be propagated. This required the generation of an inducible transgene. The tetracycline-regulatable system (tet-off) developed by Bujard and colleagues (Gossen and Bujard 1992) has been shown to confer inducibility on transgene expression in several cell types in culture and in the intact animal. However, it has proven problematic to establish this two-component system in ES cells. This is probably due to a combination of the relatively toxic effects of the tet repressor-VP16 fusion (tTA) and the tendency of ES cells to suppress expression of integrated transgenes (silencing). We have isol ated previously an ES cell line, ZHTc6, that maintains stable production of effective but nontoxic levels of tTA from a gene trap integration $(\mathrm{H}$. N iwa and A. Smith, in prep.). This cell line also contains a tetracycline-responsive $\mathrm{hCMV}^{*}$-1 transgene integrated at a favorable expression site. Expression of such transgenes is usually deregulated and/or mosaic in ES cells because of the sensitivity of the hCMV*-1 promoter to site of integration effects and silencing. However, transgene expression in lineZHTc6 is completely repressed in the presence of tetracycline but is activated in all cells on withdrawal of tetracycline as revealed by $\beta$-galactosidase reporter expression $(\mathrm{H}$. Niwa and $\mathrm{A}$. Smith, in prep.). Because of the low efficiency of establishing de novo transgene integrations with such favorable characteristics, we adopted a transgene substitution approach to generate an inducible ST AT 3F transgene.

A targeting vector was designed for introduction of the ST AT 3F sequences into the hCMV*-1 locus by homologous recombination, using $5^{\prime}$ and $3^{\prime}$ sequences from the original transgenic construct as homol ogy arms (Fig. 5A).
In the presence of tetracycline, ZHT c6 cells are sensitive to $\mathrm{G} 418$ because the $\mathrm{hCMV*-1}$ promoter is repressed. Advantage was taken of this by including a constitutive $\mathrm{MCl}$ enhancer/promoter in the supertargeting vector to drive selectable marker expression. The absence of the neo sequence, however, requires that a legitimate recombination event with the resident transgene occur to confer $\mathrm{G} 418$ resistance. This powerful selection facilitated the isolation of targeted clones in which the STAT3F sequence was faithfully integrated $3^{\prime}$ to the $h C M V *-1$ promoter (Fig. 5B). In the continued presence of tetracycline, the targeted cells were maintained readily as un-

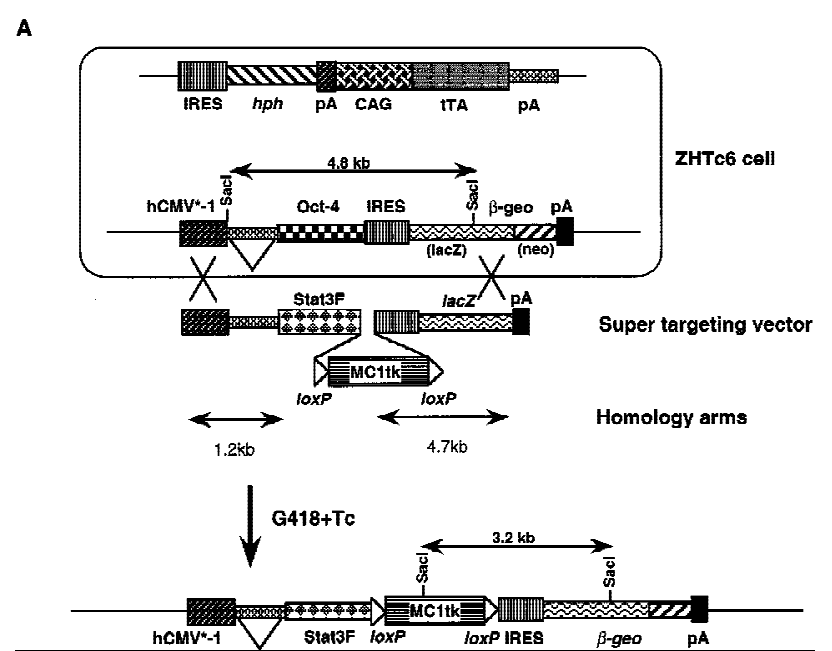

B

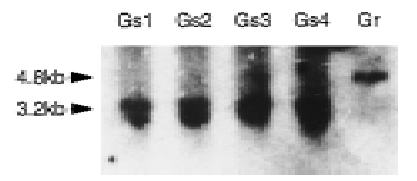

Figure 5. Generation of an inducible STAT 3F transgene integration by supertargeting. (A) Schematic of supertargeting strategy for introduction of STAT3F into a tetracycline-regulatable expression site. ZHT c6 ES cells contain a tetracycline-regulated transgene comprising the hCM $\mathrm{C}^{*}-1$ promoter (Gossen and Bujard 1992), $\beta$-globin second intron, Oct-4 open reading frame (Okazawa et al. 1991), and IRES $\beta$ geopA selection marker (Mountford et al. 1994). Homologous recombination can be used to replace the Oct-4 sequence (supertargeting). Use of a truncated selection marker in the targeting vector facilitates the isolation of homologous recombinants. ZHTc6 cells were electroporated with the STAT3F-SuperKO vector and selected in G418 in the presence of tetracycline. G418-resistant clones were duplicated and screened for sensitivity against gancycl ovir to enrich further for homologous recombinants. The option of excising the loxP-flanked MC1tk cassette by transient expression of Cre recombinase was not pursued. (B) Diagnosis of the supertargeting event in Gs ES cells. Gancycl ovir-sensitive (Gs; lanes 1-4) and -resistant ( $\mathrm{Gr}$; lane 5) clones were analyzed by Southern hybridization. A 3.2-kb Sacl fragment was detected with a probe from the $5^{\prime}$ end of lacZ in the Gs samples, indicative of the correct replacement of the Oct-4 cDN A sequence with STAT3F sequence. The Gr clone retained the 4.8-kb fragment diagnostic for the original Oct-4 transgene integration in ZHTc6 cells. 


\section{Niwa et al.}

differentiated stem cell colonies in the presence of LIF. Three clones, Gs1, Gs2, and Gs3, were then analyzed further.

Induced expression of STAT3F blocks ES cell self-renewal and causes differentiation

Withdrawal of tetracycline from Gs1, Gs2, or Gs3 cells resulted in the induction of differentiation in all three clones (Fig. 6A-C). Importantly, the efficiency of colony formation was not significantly different in the presence or absence of tetracycline, indicating that there is no toxic effect of STAT 3F induction. The induced cultures differentiated over a 3- to 4-day time period, paralleling the behavior of parental ES cells on removal of LIF (Smith 1991). The differentiation response was confirmed by Northern hybridization analysis of Rex- 1 and H19 transcripts (data not shown).

Mobility retardation analysis was used to investigate directly STAT3 activation in STAT3F-expressing ES cells. The data in Figure 6D show that the level of STAT 3 DN A-binding activity induced by gp130 stimu-

A

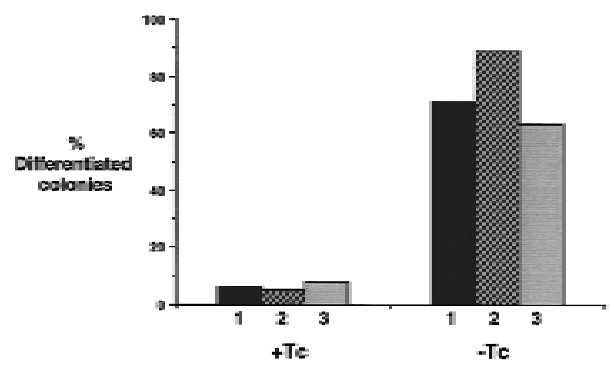

$\mathbf{B}$

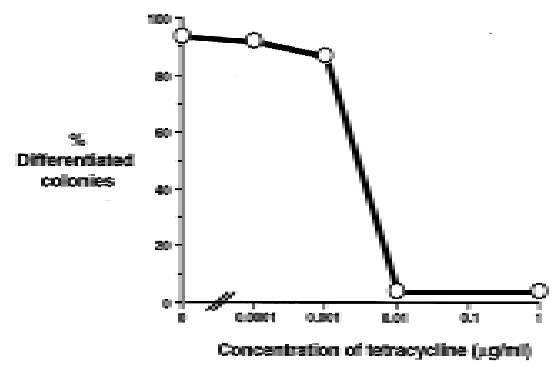

c

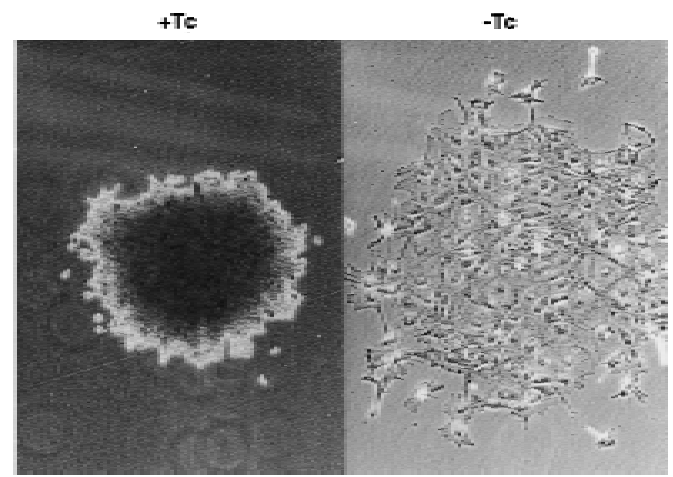

D

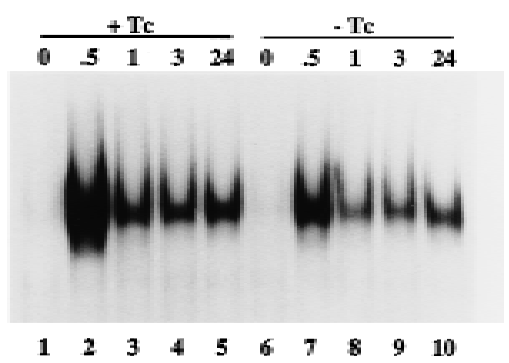

$\begin{array}{llllllllll}1 & 2 & 3 & 4 & 5 & 6 & 7 & 8 & 9 & 10\end{array}$

Figure 6. Induced expression of STAT3F causes ES cell differentiation and inhibits STAT3 activation. (A) Differentiation of Gs ES cells induced by withdrawal of tetracycline. Gs ES cells grown up in the presence of tetracycline were plated at clonal density (500 cells/60-mm dish) in LIF-supplemented medium in the presence or absence of tetracycline $(1 \mu \mathrm{g} / \mathrm{ml})$. After 6 days, colonies were fixed and stained with Leishman's reagent. The histogram records the proportions of differentiated colonies for three independent clones, Gs1 (solid bars), Gs2 (hatched bars), and Gs3 (shaded bars). (B) Dose response curve of Gs2 cell differentiation. Gs2 ES cells were cultured as above in the presence of the indicated concentrations of tetracycline, then fixed, stained, and scored. (C) Photomicrographs of uninduced and induced Gs2 ES cells. Representative colonies of Gs2 cells cultured for 6 days in LIF-supplemented medium in the presence $(+\mathrm{T} \mathrm{c})$ or absence $(-\mathrm{Tc})$ of tetracycline $(1 \mu \mathrm{g} / \mathrm{ml})$ and then fixed and stained with Leishman's reagent. (D) M obility retardation assay of STAT3 DN A-binding activity in noninduced and induced Gs2 cells. Gs2 ES cells were cultured for $72 \mathrm{hr}$ in the presence or absence of tetracycline. IL-6/sIL-6R was withdrawn for the final $24 \mathrm{hr}$, then restored for the indicated times. Nuclear extracts were prepared and assayed as described for SIE DN A-binding activity. (E) Quantitation of STAT3 SIE binding by Phosphorlmager. (Shaded bars) $+\mathrm{T}$ c; (open bars) $-\mathrm{Tc}$. 
Iation was significantly lower in the presence of STAT 3F. Quantitative Phosphorlmager analysis confirmed a reduction of $50 \%$ or greater in the gel shift signal at all time points (Fig. 6E). The presence of residual STAT3 activity is consistent with the notion that a threshold level of active STAT 3 is required to sustain self-renewal.

These findings confirm that expression of STAT3F in ES cells reduces gp130-mediated activation of STAT3, thereby blocking self-renewal and promoting differentiation.

\section{Discussion}

The primary cytopl asmic signal transduction event emanating from a ligand-activated LIF-R/gp130 complex in ES cells as in other cell types is considered to be transphosphorylation and activation of receptor-associated Janus kinases (JAKs) (Davis et al. 1993; Narazaki et al. 1994). The JAKs then phosphorylate tyrosine residues in the receptors, creating docking sites for $\mathrm{SH} 2$ domaincontaining proteins, notably including the STAT factors STAT 1 and STAT3 (Lutticken et al. 1994; Stahl et al. 1995). STAT proteins are themselves targets for phosphorylation by JAKs, which leads to their dimerization and translocation to the nucleus. Other signal transducing molecules can also be activated downstream of gp130, including insulin receptor substrate-1 (IRS-1), phosphoi nositide-3 kinases (PI-3 kinase), nonreceptor tyrosine kinases such as Hck and Btk, the tyrosine phosphatase SHP2, and the mitogen-activated protein kinases ERK1 and ERK2 (Boulton et al. 1994; Ernst et al. 1994; Y in and Yang 1994; Argetsinger et al. 1995; Matsuda et al. 1995a,b). This modular signaling system has been assumed to underlie the diverse and pleiotropic effects of IL-6 and LIF-related cytokines in different cell types. A key issue therefore is to resolve the relative contribution of different signaling pathways in any given responsive cell type. A critical role has been ascribed to SHP2-mediated activation of the MAP kinase cascade in prol iferation of BAF-BO3 cells (Fukada et al. 1996) and suppression of apoptosis in cardiomyocytes (Sheng et al. 1997). In contrast, the differentiation responses of myel oid M 1 cells (Minami et al. 1996; N akajima et al . 1996) and primary neural precursors (Bonni et al. 1997) are effected via activation of STAT3. Previous studies in ES cells have suggested that JAK-STAT signaling, ERK activation, and the nonreceptor tyrosine kinase Hck could all be involved in LIF signaling (Ernst et al. 1994, 1996; N arazaki et al. 1994; Hocke et al. 1995; Boeuf et al. 1997).

We initially investigated the ability of chimeric receptor constructs to signal ES cell self-renewal by isolation of stably expressing transfectants. The observation that G-CSF-R can support ES cell propagation drew attention to signaling features conserved between G-CSF-R and gp130, notably the induction of STAT3 DNA-binding activity. Combined substitutions of the tyrosine residues in the STAT3 binding sites of gp130 cytoplasmic domain were associated with different levels of ST AT 3 activation and indicated that a self-renewal signal is as- sociated with a threshold of STAT3 activity. Moreover, the four STAT3 sites do not appear to act in either a redundant or simple cumulative manner. Both self-re newal signaling and induction of STAT3 DNA-binding activity were maintained on pairwise mutation of the two-membrane proximal ST AT 3 docking sites (Y 126 and $Y 173$ ) but not on mutation of the carboxy-terminal pair (Y265 and Y 275) (see Fig. 2). This observation is somewhat unexpected as it has been shown previously that the isolated phosphopeptide sequences have equivalent ST AT 3 binding properties (Stahl et al. 1995) and that a truncated receptor with a single-membrane proximal STAT 3 site (Y 126) can efficiently induce STAT3-mediated differentiation of M 1 cells (Yamanaka et al. 1996). It is important to note, however, that in the truncated receptor, sequences that mediate receptor internalization (Dittrich et al. 1996) have al so been del eted with unpredictable consequences for signal ing properties. Our findings indicate that in the normal context of the fulllength receptor, the four STAT3 docking sites are not equivalent. The explanation for the reduced activity of the membrane proximal pair of sites is unclear though one possibility is that availability of $Y 126$ may be influenced by interaction of SHP2 with Y 118 (note enhanced ERK activation from Y 126-275F chimera in Fig. 2E).

The finding that mutation of the ST AT 3 binding sites in the cytoplasmic domain of gp130 abolished the selfrenewal signal prompted a direct investigation of the role of this transcription factor. $\mathrm{N}$ ew strategies were required to express the dominant interfering mutant ST AT $3 F$ in ES cells. The methods we have deployed in this study enhance the experimental versatility and tractability of ES cells and establish new avenues for the characterization in vitro of gene functions involved in stem cell propagation, commitment, or differentiation. Because of the $>100$-fold increase in stable transfection efficiency and the relative homogeneity of expression $(\mathrm{H}$. N iwa, I. Chambers, L. Forrester, M. Gassmann, and A.G. Smith, in prep.), episomal supertransfection provides a methodology for the screening and analysis of cDNAs whose expression is not compatible with ES cell self-renewal. The first demonstration of effective operation of the tetracycline regulation system in ES cells provides a complementary inducible expression approach. These two methods should find broad application in functional screening and in the genetic manipulation of lineage commitment and differentiation processes in ES cells.

Both constitutive expression of ST AT 3F following episomal supertransfection and induced expression from the regulatable chromosomal site inhibited self-renewal and resulted in differentiation. The episomal approach also allowed the specificity of the requirement for STAT3 to be established by coexpression of various STAT family members with STAT BF. The finding that ST AT 3 can restore self-renewal indicates that this factor serves a specific and nonredundant function in ES cell self-renewal in response to LIF. The evidence that ST AT 1 cannot compensate for ST AT 3 is noteworthy be cause STAT 1 can be activated in response to LIF in ES cells, though to a much lesser extent than STAT3 (Starr 
et al. 1997). STAT1 may play little or no role in ES cell propagation. Induction of STAT 1 DNA-binding activity was not evidently associated with self-renewal signaling from the various chimeric receptors used in this study (Figs. 1B and 2D). Furthermore, ES cells in which both alleles of the stat1 gene have been inactivated are phenotypically normal (Durbin et al. 1996).

A role for STAT3 in ES cell signaling has recently al so been suggested by Boeuf et al. (1997) who reported the isolation of ES cell clones expressing ST AT 3F constitutively. These cells apparently showed an increased tendency to differentiate after 1 month or more in culture. The basis of this phenomenon is unclear because absence or blockade of LIF signaling results in complete differentiation within a few days (Smith et al. 1988; Williams et al. 1988; C. Dani, I. Chambers, S. Johnstone, M. Robertson, B. Ebrahimi-Chahardahcherik, M. Saito, T. Taga, M. Li, T. Burdon, J. Nichols, and A.G. Smith, in prep.). We were unable to establish conventional transfectants expressing significant levels of STAT 3F. However, our data on both episomal and induced expression demonstrate that STAT 3F rapidly and efficiently blocks ES cell self-renewal and triggers differentiation.

Our results establish that STAT 3 activation is essential for LIF-R/gp130-mediated ES cell self-renewal. ST AT 3 activity is regulated by phosphorylation on both tyrosine and serine (Wen et al. 1995), and a constitutively active mutant has not been described. An isoform of STAT 3, STAT $3 \beta$, generated by alternative splicing, is reported to show sustained activation properties (Schaefer et al. 1995). ES cells supertransfected with a STAT3 $\beta$ vector remained LIF dependent (data not shown), however, indicating that this isoform does not substitute for activated STAT3 in ES cells. This may be because STAT $3 \beta$ appears to function by formation of heterodimers with c-Jun (Schaefer et al. 1995), and it is anticipated that the ST AT $3 \beta /$ c-Jun complex regulates a distinct spectrum of target genes compared with the STAT3 homodimer. It is noteworthy, however, that expression of v-src in ES cells renders them LIF independent (Boulter et al. 1991). v-Src has been shown to associate with and cause constitutive activation of STAT3 (Cao et al. 1996).

The p42/p44 MAP kinase pathway (ERK1 and ERK2) has been reported to be activated by LIF in ES cells as in other cell types (Ernst et al. 1996; Boeuf et al. 1997). The Ras-ERK cascade is coupled to gp130 via the adaptor molecule SHP2 (Fukada et al. 1996; Yamanaka et al. 1996). SHP2 interacts with activated gp130 at phosphorylated tyrosine residue 118 (Stahl et al. 1995). Significantly, mutation of this residue does not inhibit selfrenewal signaling in ES cells (T. Burdon, I. Chambers, C. Stracey, J. Nichols, and A.G. Smith, in prep.). Furthermore, the MEK inhibitor PD 098059 (Dudley et al. 1995) that specifically blocks activation of the ERK kinases does not inhibit stem cell colony formation in response to LIF (T. Burdon, I. Chambers, C. Stracey, J. N ichols, and A.G. Smith, in prep.). Thus, although contributions of other pathways are not precluded, STAT 3 appears to play a central role in ES cell self-renewal. The underlying importance of ST AT 3 is further attested to by the finding that homozygous disruption of the Stat3 gene in mice is associated with early embryonic lethal ity (T akeda et al. 1997).

It is striking that the role of STAT3 in propagation of the undifferentiated pluripotential phenotype of ES cells contrasts with previously characterized functions as an effector of somatic cell differentiation. Dominant interfering mutants of ST AT 3 have been shown to bl ock macrophage differentiation of myeloid $\mathrm{M} 1$ cells induced by IL-6 or LIF (M inami et al. 1996; N akajima et al. 1996) or by GCSF (Shimozaki et al. 1997). ST AT3 activation has similarly been shown to mediate IL-6- or LIF-induced astrocytic differentiation of primary cortical neuroepithelial cells (Bonni et al . 1997). Recently it has al so been shown that STAT3 is activated by hepatocyte growth factor and mediates epithelial tubulogenesis (Boccaccio et al. 1998). STAT 3 thus has distinct effects in different cell types. A common theme, however, may be the regulation of genes that determine cell identity. The diverse effects of the LIF/IL-6 family of cytokines on cellular differentiation and gene expression appear to reflect celltype specific effects of active STAT3. In the context of stem cell propagation, the key issue now is to identify transcriptional targets of STAT3 in ES cells and to illuminate the relationship between STAT 3 and the essential ES cell-specific transcription factor Oct-4.

\section{Materials and methods}

\section{Cell culture and transfection}

ES cells were maintained in the absence of feeder cells in Glasgow modification of Eagle medium (GM EM) supplemented with fetal calf serum, 2-mercaptoethanol, and LIF (Smith 1991). CGR8 (Mountford et al. 1994) and M G1.19 (Gassmann et al. 1995) ES cells have been described elsewhere. DO27 ES cells have had both copies of the lif gene inactivated by homologous recombination and the IRES $\beta$ geo selection marker/reporter inserted into the oct4 gene as described (C. Dani, I. Chambers, S. Johnstone, M. Robertson, B. Ebrahimi-Chahardahcherik, M. Saito, T. Taga, M. Li, T. Burdon, J. Nichols, and A.G. Smith, in prep.). LRKOh34 ES cells have targeted disruptions in both copies of the lifr gene (M. Li, I. Chambers, J. Nichols, and A.G. Smith, in prep.) and are maintained in medium in which LIF is substituted with IL-6 $(50 \mathrm{ng} / \mathrm{ml})$ and soluble IL-6 receptor $(5 \%$ CHO-5E7 conditioned medium; Yasukawa et al. 1990). For conventional transfection with pPCAGIZ vectors, $1 \times 10^{7}$ cells were el ectroporated with $100 \mu \mathrm{g}$ of linearized plasmid DN A at $800 \mathrm{~V}$ and $3 \mu \mathrm{F}$ in a 0.4-cm cuvette using a Bio-Rad gene pulser and then selected in the presence of zeocin (Invitrogen). For transfection of episomal vectors (supertransfection), $5 \times 10^{6}$ MG1.19 cells were electroporated with $20 \mu \mathrm{g}$ of supercoiled plasmid DNA at $200 \mathrm{~V}$ and $960 \mu \mathrm{F}$ and then cultured in the presence of either $80 \mu \mathrm{g} / \mathrm{ml}$ hygromycin B (Boehringer Mannheim) or $4-20 \mu \mathrm{g} / \mathrm{ml}$ blasticidin S (Waken Seiyaku), or both hygromycin plus blasticidin for cosupertransfection.

\section{Generation of tetracycline regulatable transgenes in ES cells}

ZHT c6 ES cells were derived from CGR8 ES cells (M ountford et al. 1994) and will be described in detail el sewhere (H. N iwa and A.G. Smith, in prep.). They carry a targeted integration of IRESzeo in one Oct3/4 allele. They al so carry a gene trap inte- 
gration of an IREShph:CAGtTA construct that confers stable expression of the tetracycline-responsive tTA transactivator and a randomly integrated $\mathrm{hCMV*-1-Oct4-IRES \beta geopA}$ transgene. These cells were routinely maintained in the presence of $10 \mu \mathrm{g} / \mathrm{ml}$ zeocin and $1 \mu \mathrm{g} / \mathrm{ml}$ tetracycline $\mathrm{HCl}$ (Sigma).

The hCMV*-1-Oct-4-IRESßgeopA transgene is comprised of the tetracycline-inducible promoter $\mathrm{hCMV}^{*}-1$ derived from pUHD10-3 (Gossen and Bujard 1992), rabbit $\beta$-globin second intron, full-length Oct-4 CDNA, and IRESßgeopA unit (M ountford et al. 1994). pSuperKO (see Fig. 5A) contains the hCM V*-1 and rabbit globin sequences as the $5^{\prime}$ homology arm and the IRESlacZ cassette as $3^{\prime}$ arm. Intervening are a stuffer sequence with Xhol and Sfil cloning sites and a loxP-flanked MC1tk cassette ( $M$ ansour et al. 1988). The STAT 3F CDN A was introduced as a Sall fragment between the Xhol sites. For gene targeting, $2 \times 10^{7}$ cells were electroporated with $100 \mu \mathrm{g}$ linearized SuperKO-STAT3F plasmid DNA at $800 \mathrm{~V}$ and $3 \mu \mathrm{F}$ and then selected in the presence of $200 \mu \mathrm{g} / \mathrm{ml} \mathrm{G} 418$ (GIBCO BRL) and 1 $\mu \mathrm{g} / \mathrm{ml}$ tetracycline- $\mathrm{HCl}$. Targeted clones were maintained in the continuous presence of tetracycline- $\mathrm{HCl}$.

\section{Plasmid construction}

DNA manipulations were performed by standard procedures (Sambrook et al. 1989). Full details of plasmid constructions are available on request. The full-length mouse G-CSF-R CDNA (pJ17) was provided by Shigekazu N agata (Fukunaga et al. 1990), and the G-CSF-R/LIF-R chimeric receptor construct (Baumann et al. 1994b) was provided by Steve Ziegler. G-CSF-R/gp130 chimeric receptor constructs were generated by fusing the coding sequence for the extracellular domain of human G-CSF-R (Baumann et al. 1994b) to an EcoRI fragment encoding the transmembrane domain and the entire cytoplasmic region of mouse gp130 cDNA (Hibi et al. 1990). Phenylalanine substitutions were introduced into the intracellular domain of gp130 by PCR overlap mutagenesis (Higuchi et al. 1988). PCR products were substituted into the G-CSF-R/gp130 chimera and sequenced. Episomal expression vectors pHPCAG, pBPCAG, and pHPPGK are described el sewhere (H. N iwa, I. Chambers, L. Forrester, M. Gassmann, and A.G. Smith, in prep.). The expression vector pPCAGIZ, which can be used as both an episomal and an integrated expression vector, was constructed by ligation of the encephal omyocarditis virus IRES (pCITE-1, N ovagen) with the Streptoalloteichus bleomycin resistant gene (Sh ble:zeo) from pZeoSV (Invitrogen) and introduction into pPCAG (H. Niwa, I. Chambers, L. Forrester, M. Gassmann, and A.G. Smith, in prep.). cDN As are inserted into a Xhol site 5 ' to the IRES. The requirement for continuous relatively high-level expression of the zeo gene to confer antibiotic resistance al lows direct selection for integrations into favorable expression sites. Consequently, using this vector, ES cell transfectants can readily be isolated that sustain stable transgene expression $(\mathrm{H}$. Niwa, $\mathrm{T}$. Burdon, I. Chambers, and A.G. Smith, unpubl.).

\section{RNA and DNA hybridization analyses}

Total RN A (Chomczynski and Sacchi 1987) was separated on a $0.66 \mathrm{M}$ formal dehyde, $0.8 \%$ agarose gel and blotted onto nylon membranes (Hybond $\mathrm{N}$, Amersham). Hybridization was performed with $\beta$-globin third exon, Rex-1, H19, and GAPDH cDN A probes labeled by random hexamer primed DNA synthesis in the presence of $\left[\alpha-{ }^{32} \mathrm{P}\right] \mathrm{dCTP}(3000 \mathrm{Ci} / \mathrm{mmole})$.

For identification of targeted ES cell clones, genomic DNA was digested with Sacl, separated on a $0.7 \%$ agarose gel, and analyzed by nonradioactive filter hybridization (Gene Image, Amersham) with an EcoRI-Sacl fragment of the lacZ gene.

\section{G-CSF-R binding assay}

ES cells $\left(1 \times 10^{6}\right)$ were seeded in wells of a 24 -well plate and grown for $24 \mathrm{hr}$. The cells were then cooled to $4^{\circ} \mathrm{C}$ and growth medium was replaced with $0.25 \mathrm{ml}$ of ice-cold binding buffer (GMEM , 25 mM HEPES at pH 7.2, 0.2\% BSA) containing 0.212 nM ${ }^{125}$ I-label ed G-CSF-R (A mersham) in the presence or absence of a 1000-fold molar excess of cold G-CSF-R. Binding reactions were incubated for $3 \mathrm{hr}$ at $4^{\circ} \mathrm{C}$ and terminated by washing the cells three times with ice-cold binding buffer. Cells were then solubilized in $0.5 \%$ NP-40, and an aliquot was counted in a gamma counter. All treatments were performed in duplicate. No specific binding was detected to untransfected cells, and nondisplaceable binding was consistent between clones.

\section{Self-renewal assays}

To measure self-renewal of ES cells at cloning density, cells were plated at 1000 cells per well $\left(\sim 100 \mathrm{cells} / \mathrm{cm}^{2}\right)$ in 6 -well dishes and cultured for 6 days. Cells were either grown in the absence of cytokines, in $100 \mathrm{U} / \mathrm{ml}$ recombinant LIF (Smith 1991), in $100 \mathrm{ng} / \mathrm{ml}$ IL-6 plus soluble IL-6R, or in $30 \mathrm{ng} / \mathrm{ml}$ G-CSF-R, as appropriate. On day 6, colonies were fixed and stained with Leishman's reagent (Smith 1991) or for alkaline phosphatase activity (Sigma leukocyte al kal ine phosphatase kit) (Bernstine et al. 1973). N umbers of stem cell and differentiated colonies were scored by microscopic examination, in some cases with computer-assisted image analysis. All assays were performed in duplicate or triplicate.

Stem cell-specific expression of $\beta$-gal actosi dase from the oct4 locus in D027 cells was quantified by ON PG assay on triplicate samples. Cells were plated at 5000 per well in 24-well dishes and cultured for 6 days in the presence or absence of cytokine as above. On day 6 , cells were washed once with PBS and lysed in $0.4 \mathrm{ml}$ of $0.25 \mathrm{M}$ Tris (pH 7.5), $5 \mathrm{~mm}$ DTT, and 0.5\% NP-40. Lysate $(40 \mu \mathrm{l})$ was mixed with $100 \mu \mathrm{l}$ of ONPG buffer $(60 \mathrm{~mm}$ $\mathrm{Na}_{2} \mathrm{HPO}_{4}, 40 \mathrm{~mm} \mathrm{NaH}{ }_{2} \mathrm{PO}_{4}, 10 \mathrm{~mm} \mathrm{KCl}, 1 \mathrm{~mm} \mathrm{M} \mathrm{gCl}, 50 \mathrm{~mm}$ 2-mercaptoethanol, $1.2 \mathrm{mM}$ ONPG) in a microtiter plate and incubated at $37^{\circ} \mathrm{C}$ for $2-4 \mathrm{hr}$, and the absorbance was read at $420 \mathrm{~nm}$.

\section{Preparation of nuclear extracts and band-shift assays}

One day after plating ( $1 \times 10^{6}$ cells per $60-\mathrm{mm}$ dish), ES cells were washed with PBS and refed with medium lacking cytokines. The next day, cells were stimulated with IL-6 $(100 \mathrm{ng} / \mathrm{ml}$ plus sol uble receptor) or G-CSF-R $(30 \mathrm{ng} / \mathrm{ml})$ for $30 \mathrm{~min}$, washed with ice-cold PBS, scraped off the plates, and collected by centrifugation. Nuclear extracts were prepared by the method described (Gobert et al. 1996) except that protease inhibitors (aprotinin, pepstatin, and leupeptin) were omitted from the cell lysis buffer. Protein concentrations of nuclear extracts were determined using a Bradford assay (Bio-Rad). Aliquots $(2 \mu \mathrm{g})$ of nuclear extract were incubated with $0.25 \mathrm{ng}$ of ${ }^{32} \mathrm{P}$-labeled double-stranded SIEm67 oligonucleotide probe (Sadowski et al. 1993) in binding buffer (20 mM HEPES at pH 7.5, $50 \mathrm{~mm} \mathrm{NaCl}$, $1 \mathrm{~mm}$ EDTA, $1 \mathrm{~mm}$ DTT, 0.05\% N P-40, 10\% glycerol, 2 $\mu \mathrm{g} / \mathrm{ml}$ of poly[d(I-C)], and $1 \mathrm{mg} / \mathrm{ml} \mathrm{BSA}$ ) for $20 \mathrm{~min}$ at room temperature. Binding reactions were resolved by electrophoresis on a prerun $5 \%$ polyacrylamide gel in $0.25 \times$ TBE for $3 \mathrm{hr}$. Gels were fixed in $10 \%$ acetic acid, dried under vacuum, and subjected to autoradiography or quantitated on a Bio-Rad Phosphorlmager.

Immunoblotting

One day after plating ( $1 \times 10^{6}$ cells per $60-\mathrm{mm}$ dish), ES cells were refed with medium containing $1 \%$ FCS and lacking cyto- 
kines. Following overnight incubation, cells were transferred to serum-free medium for $4 \mathrm{hr}$ prior to stimulation with IL-6 (100 $\mathrm{ng} / \mathrm{ml}$ plus soluble receptor) or G-CSF-R $(30 \mathrm{ng} / \mathrm{ml}$ ) for $20 \mathrm{~min}$. Cells were then washed once with ice-cold PBS and Iysed on ice in $100 \mu \mathrm{l}$ SDS sample buffer. Ten- microliter aliquots of the Iysates were fractionated on a 10\% SDS-polyacrylamide gel and electroblotted onto nitrocellulose. After overnight treatment in blocking buffer $(25 \mathrm{~mm}$ Tris- $\mathrm{HCl}$ at $\mathrm{pH} 7.4,2.7 \mathrm{~mm} \mathrm{KCl}, 140 \mathrm{~mm}$ $\mathrm{N} \mathrm{aCl}, 0.1 \%$ Tween $20,5 \%$ nonfat dried milk), membranes were probed sequentially with the phospho-specific anti-ERK and anti-STAT3 antibodies according to the directions provided by the supplier (N ew England Biolabs). Blots were incubated with HRP-coupled anti-rabbit IgG and developed using ECL reagents (Amersham). Membranes were stripped between probings by incubation at $50^{\circ} \mathrm{C}$ for $30 \mathrm{~min}$ in $62.5 \mathrm{~mm}$ Tris- $\mathrm{HCl}(\mathrm{pH} \mathrm{6.8),} 2 \%$ SDS, and $100 \mathrm{~mm}$ 2-mercaptoethanol.

\section{Acknowledgments}

We thank Alexander M edvinsky and John Bishop for comments on the manuscript. Craig Stracey is thanked for help with $\beta$ galactosidase assays, and Melany Jackson for assistance with image analysis. DO27 and LRKOh34 cells were generated by Christian Dani and Meng Li, respectively. We are grateful to Shizuo Akira and Daniel N athans for the STAT 3F and STAT $3 \beta$ constructs, respectively, James Darnell for STAT1 and STAT4 CDNAs, K. Akagi and Hermann Bujard for the tTA and hCMV*-1 constructs, and Tetsuya Taga for gp130 cDN A and recombinant IL-6 and sI L-6R. Recombinant G-CSF-R was a generous gift of Chugai Corporation. Photographic reproductions were by Graham Brown and colleagues. This work was supported by the Biotechnology and Biological Sciences Research Council of the United Kingdom, the Human Frontiers Science Program Organisation, and Stem Cell Sciences Pty.

The publication costs of this article were defrayed in part by payment of page charges. This article must therefore be hereby marked "advertisement" in accordance with 18 USC section 1734 solely to indicate this fact.

\section{References}

Argetsinger, L.S., G.W. Hsu, M.G. Myers, N. Billestrup, M.F. White, and C. Carter-Su. 1995. Growth hormone, interferon$\gamma$, and leukemia inhibitory factor promoted tyrosyl phosphorylation of insulin receptor substrate-1. J. Biol. Chem. 270: 14685-14692.

Baumann, H. and G.G. Wong. 1989. Hepatocyte-stimulating factor-III shares structural and functional identity with leukemia-inhibitory factor. J. Immunol. 143: 1163-1167.

Baumann, H., D. Gearing, and S. Ziegler. 1994a. Signal ing by the cytoplasmic domain of hematopoietin receptors involves two distinguishable mechanisms in hepatic cells. J. Biol. Chem. 269: 16297-16304.

Baumann, H., A.J. Symes, M.R. Comeau, K.K. M orella, Y. Wang, D. Friend, S.F. Ziegler, J.S. Fink, and D.P. Gearing. 1994b. $\mathrm{M}$ ultiple regions within the cytoplasmic domains of the leukemia inhibitory factor receptor and gp130 cooperate in signal transduction in hepatic and neuronal cells. Mol. Cell. Biol. 14: 138-146.

Bernstine, E.G., M.L. Hooper, S. Grandchamp, and B. Ephrussi. 1973. Alkaline phosphatase activity in mouse teratoma. Proc. Natl. Acad. Sci. 70: 3899-3903.

Boccaccio, C., M. Ando, L. Tamagnone, A. Bardelli, P. Michieli, C. Battistini, and P. Comoglio. 1998. Induction of epithelial tubules by growth factor HGF depends on the STAT path- way. Nature 391: 285-288.

Boeuf, H., H. Hauss, F. De Graeve, N. Baran, and N. Kedinger. 1997. Leukemia inhibitory factor-dependent transcriptional activation in embryonic stem cells. J. Cell Biol. 138: 12071217.

Bonni, A., Y. Sun, M. N adal-Vicens, A. Bhatt, D.A. Frank, I. Rozovsky, N. Stahl, G.D. Yancopoulos, and M .E. Greenberg. 1997. Regulation of gliogenesis in the central nervous system by the JAK-STAT signaling pathway. Science 278: 477483.

Boulter, C.A., A. Aguzzi, R.L. Williams, E.F. Wagner, M.J. Evans, and R. Beddington. 1991. Expression of V-src induces aberrant development and twinning in chimaeric mice. Development 111: 357-366.

Boulton, T.G., N. Stahl, and G.D. Yancopoulos. 1994. Ciliary neurotrophic factor/leukemia inhibitory factor/interleukin$6 /$ oncostatin M family of cytokines induces tyrosine phosphorylation of a common set of proteins overlapping those induced by other cytokines and growth factors. J. Biol. Chem. 269: 11648-11655.

Brook, F.A. and R.L. Gardner. 1997. The origin and efficient derivation of embryonic stem cells in the mouse. Proc. Natl. Acad. Sci. 94: 5709-5712.

Cao, X., A. Tay, G.R. Guy, and Y.H. Tan. 1996. Activation and association of stat3 with src in v-src-transformed cell lines. Mol. Cell. Biol. 16: 1595-1603.

Chambers, I., A. Cozens, J. Broadbent, M. Robertson, M. Lee, M. $\mathrm{Li}$, and A. Smith. 1997. Structure of the mouse leukaemia inhibitory factor receptor gene: Regulated expression of mRN A encoding a soluble receptor isoform from an alternative $5^{\prime}$ untranslated region. Biochem. J. 328: 879-888.

Chomczynski, P. and N. Sacchi. 1987. Single-step method of RNA isolation by acid guanidinium thiocyanate-phenolchloroform extraction. Anal. Biochem. 162: 156-159.

Conover, J.C., N.Y. Ip, W.T. Poueymirou, B. Bates, M.P. Goldfarb, T.M. DeChiara, and G.D. Yancopoulos. 1993. Ciliary neurotrophic factor maintains the pluripotentiality of embryonic stem cells. Development 119: 559-565.

Davis, S., T.H. Aldrich, N. Stahl, L. Pan, T. Taga, T. Kishimoto, N.Y. Ip, and G.D. Yancopoulos. 1993. LIFR $\beta$ and gp130 as heterodimerizing signal transducers of the tripartite CNTF receptor. Science 260: 1805-1808.

Dittrich, E., C.H. Haft, L. Muys, P.C. Heinrich, and L. Graeve. 1996. A di-leucine motif and an upstream serine in the interleukin-6 (IL-6) signal transducer gp130 mediate ligandinduced endocytosis and down-regulation of the IL-6 receptor. J. Biol. Chem. 271: 5487-5494.

Dudley, D.T., L. Pang, S.J. Decker, A.J. Bridges, and A.R. Saltiel. 1995. A synthetic inhibitor of the mitogen-activated protein kinase cascade. Proc. Natl. Acad. Sci. 92: 7686-7689.

Durbin, J.E., R. Hackenmiller, M.C. Simon, and D.E. Levy. 1996. Targeted disruption of the mouse statl gene results in compromised innate immunity to viral disease. Cell 84: 443-450.

Ernst, M., D.P. Gearing, and A.R. Dunn. 1994. Functional and biochemical association of Hck with the LIF/IL-6 receptor signal transducing subunit gp130 in embryonic stem cells. EMBO J. 13: 1574-1584.

Ernst, M., A. Oates, and A.R. Dunn. 1996. Gp130-mediated signal transduction in embryonic stem cells involves activation of Jak and Ras/mitogen activated protein kinase pathways. J. Biol. Chem. 271: 30136-30143.

Evans, M.J. and M. Kaufman. 1981. Establishment in culture of pluripotential cells from mouse embryos. Nature 292: 154156.

Fukada, T., M. Hibi, Y. Yamanaka, M. Takahashi-Tezuka, Y. 
Fujitani, T. Yamaguchi, K. N akajima, and T. Hirano. 1996. Two signals are necessary for cell proliferation induced by a cytokine receptor gp130: Involvement of STAT3 in antiapoptosis. Immunity 5: 449-460.

Fukunaga, R., E. Ishizaka-lkeda, Y. Seto, and S. Nagata. 1990. Expression cloning of a receptor for murine granulocyte colony-stimulating factor. Cell 61: 341-350.

Gassmann, M., G. Donoho, and P. Berg. 1995. Maintenance of an extrachromosomal plasmid vector in mouse embryonic stem cells. Proc. Natl. Acad. Sci. 92: 1292-1296.

Gearing, D.P. and G.A. Bruce. 1992. Oncostatin M binds the high-affinity leukemia inhibitory factor receptor. New Biol. 4: 61-65.

Gearing, D.P., C.J. Thut, T. VandenBos, S.D. Gimpel, P.B. Delaney, J. King, V. Price, D. Cosman, and M.P. Beckman. 1991. Leukemia inhibitory factor receptor is structurally related to the II-6 signal transducer, gp130. EMBO J. 10: 28392848.

Gobert, S., S. Chretien, F. Gouilleux, O. Muller, C. Pallard, I. Dusanter-Fourt, B. Groner, C. Lacombe, S. Gissel brecht, and P. Mayeux. 1996. Identification of tyrosine residues within the intracellular domain of the erythropoietin receptor crucial for STAT5 activation. EMBO J. 15: 2434-2441.

Gossen, M. and H. Bujard. 1992. Tight control of gene expression in mammalian cells by tetracycline-responsive promoters. Proc. Natl. Acad. Sci. 89: 5547-5551.

Hibi, M., M. Murakami, M. Saito, T. Hirano, T. Taga, and T. Kishimoto. 1990. Molecular cloning and expression of an IL-6 signal transducer, gp130. Cell 63: 1149-1157.

Higuchi, R., B. Krummel, and R.K. Saiki. 1988. A general method of in vitro preparation and specific mutagenesis of DNA fragments: Study of protein and DNA interactions. Nucleic Acids Res. 15: 7351-7367.

Hirota, H., K. Yoshida, T. Kishimoto, and T. Taga. 1995. Continuous activation of gp130, a signal-transducing receptor component for interleukin 6-related cytokines, causes myocardial hypertrophy in mice. Proc. Natl. Acad. Sci. 92: 48624866.

Hocke, G.M., M.Z. Cui, and G.H. Fey. 1995. The LIF response element of the $\alpha 2$ macroglobulin gene confers LIF-induced transcriptional activation in embryonal stem cells. Cytokine 7: 491-502.

Ihara, S., K. N akajima, T. Fukada, M. Hibi, S. N agata, T. Hirano, and Y. Fukui. 1997. Dual control of neurite outgrowth by STAT 3 and MAP kinase in PC12 cells stimulated with interleukin-6. EMBO J. 16: 5345-5352.

Ihle, J. 1996. STATs: Signal transducers and activators of transcription. Cell 84: 331-334.

Kishimoto, T., T. Taga, and S. Akira. 1994. Cytokine signal transduction. Cell 76: 253-262.

Koblar, S.A., A.M. Turnley, B.J. Classon, K.L. Reid, C.B. Ware, S.S. Cheema, M. Murphy, and P.F. Bartlett. 1998. Neural precursor differentiation into astrocytes requires signaling through the leukemia inhibitory factor receptor. Proc. Natl. Acad. Sci. 95: 3178-3181.

Li, M., M. Sendtner, and A. Smith. 1995. Essential function of LIF receptor in motor neurons. Nature 378: 724-727.

Lutticken, C., U.M. Wegenka, J. Yuan, J. Buschmann, C. Schindler, A. Ziemiecki, A.G. Harpur, A.F. Wilks, K. Yasukawa, T. Taga, T. Kishimoto, G. Barbieri, S. Pellegrini, M. Sendtner, P.C. Heinrich, and F. Horn. 1994. Association of transcription factor APRF and protein kinase Jak1 with the interleukin-6 signal transducer gp130. Science 263: 89-92.

Mansour, S.L., K.R. Thomas, and M.R. Capecchi. 1988. Disruption of the proto-oncogene int- 2 in mouse embryo-derived stem cells: A general strategy for targeting mutations to non- sel ectable genes. N ature 336: 348-352.

M artin, G.R. 1981. Isolation of a pluripotent cell line from early mouse embryos cultured in medium conditioned by teratocarcinoma stem cells. Proc. Natl. Acad. Sci. 78: 7634-7638.

M atsuda, T., T. Fukada, M. TakahashiTezuka, Y. Okuyama, Y. Fujitani, Y. Hanazono, H. Hirai, and T. Hirano. 1995a. Activation of Fes tyrosine kinase by gp130, an interleukin-6 family cytokine signal transducer, and their association. J. Biol. Chem. 270: 11037-11039.

M atsuda, T., M. TakahashiTezuka, T. Fukada, Y. Okuyama, Y. Fujitani, S. Tsukada, H. Mano, H. Hirai, O.N. Witte, and T. Hirano. 1995b. Association and activation of Btk and Tec tyrosine kinases by gp130, a signal transducer of the interleukin-6 family of cytokines. Blood 85: 627-633.

Minami, M., M. Inoue, S. Wei, K. Takeda, M. Matsumoto, T. Kishimoto, and A. Akira. 1996. STAT3 activation is a critical step in gp130-mediated terminal differentiation and growth arrest of a myeloid cell line. Proc. Natl. Acad. Sci. 93: 3963-3966.

M ountford, P., B. Zevnik, A. Duwel, J. Nichols, M. Li, C. Dani, M. Robertson, I. Chambers, and A. Smith. 1994. Dicistronic targeting constructs: Reporters and modifiers of mammalian gene expression. Proc. Natl. Acad. Sci. 91: 4303-4307.

Murakami, M., M. Hibi, N. Nakagawa, T. Nakagawa, K. Yasukawa, K. Yamanishi, T. Taga, and T. Kishimoto. 1993. IL-6-induced homodimerization of gp130 and associated activation of a tyrosine kinase. Science 260: 1808-1810.

N akajima, K., Y. Yamanaka, K. N akae, H. Kojima, M. Ichiba, N. Kiuchi, T. Kitaoka, T. Fukada, M. Hibi, and T. Hirano. 1996. A central role for Stat3 in IL-6-induced regulation of growth and differentiation in M 1 leukemia cells. EMBO J. 15: 36513658.

Narazaki, M., B.A. Witthuhn, K. Yoshida, O. Silvennoinen, K. Yasukawa, J.N. Ihle, T. Kishimoto, and T. Taga. 1994. Activation of JAK2 kinase mediated by the interleukin 6 signal transducer gp130. Proc. Natl. Acad. Sci. 91: 2285-2289.

Nichols, J., I. Chambers, and A. Smith. 1994. Derivation of germline competent embryonic stem cells with combination of interleukin- 6 and soluble interleukin- 6 receptor. Exp. Cell Res. 215: 237-239.

Okazawa, H., K. Okamoto, F. Ishino, T. IshinoKaneko, S. Takeda, Y.M.M. Toyoda, and H. Hamada. 1991. The oct3 gene, a gene for an embryonic transcription factor, is controlled by a retinoic acid repressible enhancer. EMBO J. 10: 2997-3006.

Pennica, D., K.L. King, K.J. Shaw, E. Luis, J. Rullamas, S.-M. Luoh, W.C. Darbinne, D.S. Knutzon, R. Yen, K.R. Chien, J.B. Baker, and W.L. Wood. 1995a. Expression cloning of cardiotrophin 1, a cytokine that induces cardiac myocyte hypertrophy. Proc. Natl. Acad. Sci. 92: 1142-1146.

Pennica, D., K.J. Shaw, T.A. Swanson, M.W. Moore, D.L. Shelton, K.A. Zioncheck, A. Rosenthal, T. Taga, N .F. Paoni, and W.I. Wood. 1995b. Cardiotrophin-1. Biological activities and binding to the leukemia inhibitory factor receptor/ gp130 signaling complex. J. Biol. Chem. 270: 10915-10922.

Rathjen, P.D., J. N ichols, S. Toth, D.R. Edwards, J.K. Heath, and A.G. Smith. 1990. Developmentally programmed induction of differentiation inhibiting activity and the control of stem cell populations. Genes \& Dev. 4: 2308-2318.

Rose, T.M., D.M. Weiford, N.L. Gunderson, and A.G. Bruce. 1994. Oncostatin M (OSM) inhibits the differentiation of pluripotent embryonic stem cells in vitro. Cytokine 6: 4854.

Sadowski, H.B., K. Shuai, J.E. Darnell, and M.Z. Gilman. 1993. A common nuclear signal transduction pathway activated by growth factor and cytokine receptors. Science 261: 17391744. 
Sambrook, J., E.F. Fritsch, and T. Maniatis. 1989. Molecular cloning: A laboratory manual. Cold Spring Harbor Laboratory Press, Cold Spring Harbor, NY.

Schaefer, T.S., L.K. Sanders, and D. N athans. 1995. Cooperative transcriptional activity of jun and Stat $3 \beta$, a short form of Stat3. Proc. Natl. Acad. Sci. 92: 9097-9101.

Sheng, Z., K. Knowlton, J. Chen, M. Hoshijima, J.H. Brown, and K.R. Chien. 1997. Cardiotrophin 1 (CT-1) inhibition of cardiac myocyte apoptosis via a mitogen activated protein kinase-dependent pathway. J. Biol. Chem. 272: 5783-5791.

Shimozaki, K., K. N akajima, T. Hirano, and S. Nagata. 1997. Involvement of STAT3 in the granulocyte colony-stimulating factor-induced differentiation of myeloid cells. J. Biol. Chem. 272: 25184-25189.

Smith, A.G. 1991. Culture and differentiation of embryonic stem cells. J. Tiss. Cult. Meth. 13: 89-94.

Smith, A.G. and M.L. Hooper. 1987. Buffalo rat liver cells produce a diffusible activity which inhibits the differentiation of murine embryonal carcinoma and embryonic stem cells. Dev. Biol. 121: 1-9.

Smith, A.G., J.K. Heath, D.D. Donaldson, G.G. Wong, J. Moreau, M. Stahl, and D. Rogers. 1988. Inhibition of pluripotential embryonic stem cell differentiation by purified polypeptides. Nature 336: 688-690.

Stahl, N., T.G. Boulton, T. Farruggella, N.Y. Ip, S. Davis, B.A. Witthuhn, F.W. Quelle, O. Silvennoinen, G. Barbieri, S. Pellegrini, J.N. Ihle, and G.D. Yancopoulos. 1994. Association and activation of Jak-Tyk kinases by CNTF-LIF-OSM-IL-6 beta receptor components. Science 263: 92-95.

Stahl, N., T.J. Farrugella, T.G. Boulton, Z. Zhong, J.E. Darnell, and G.D. Yancopoulos. 1995. Choice of STATs and other substrates specified by modular tyrosine-based motifs in cytokine receptors. Science 267: 1349-1353.

Starr, R., U. N ovak, T.A. Willson, M. Inglese, V. M urphy, W.S. Alexander, D. Metcalf, N.A. Nicola, D.J. Hilton, and M. Ernst. 1997. Distinct roles for leukemia inhibitory factor receptor $\alpha$-chain and gp130 in cell type-specific signal transduction. J. Biol. Chem. 272: 19982-19986.

Takeda, K., K. N oguchi, W. Shi, T. Tanaka, M. Matsumoto, N. Yoshida, T. Kishimoto, and S. Akira. 1997. Targeted disruption of the mouse Stat3 gene leads to early embryonic lethality. Proc. Natl. Acad. Sci. 94: 3801-3804.

Tomida, M., Y. Yamamoto-Y amaguchi, and M. Hozumi. 1984. Purification of a factor inducing differentiation of mouse myeloid leukemic M 1 cells from conditioned medium of mouse fibroblast L929 cells. J. Biol. Chem. 259: 1097810982.

Wen, Z., Z. Zhong, and J.E. Darnell. 1995. Maximal activation of transcription by Stat 1 and Stat 3 requires both tyrosine and serine phosphorylation. Cell 82: 241-250.

Williams, R.L., D.J. Hilton, S. Pease, T.A. Willson, C.L. Stewart, D.P. Gearing, E.F. Wagner, D. Metcalf, N.A. Nicola, and N.M. Gough. 1988. Myeloid leukemia inhibitory factor maintains the developmental potential of embryonic stem cells. Nature 336: 684-687.

Wolf, E., R. Kramer, I. Polejaeva, H. Thoenen, and G. Brem. 1994. Efficient generation of chimeric mice using embryonic stem cells after long term culture in the presence of ciliary neurotrophic factor. Transgenic Res. 3: 152-158.

Yamamori, T., K. Fukada, R. Aebersold, S. Korsching, M.-J. Fann, and P.H. Patterson. 1989. The cholinergic neuronal differentiation factor from heart cells is identical to leukemia inhibitory factor. Science 246: 1412-1416.

Yamanaka, Y., K. N akajima, T. Fukada, M. Hibi, and T. Hirano. 1996. Differentiation and growth arrest signals are generated through the cytoplasmic region of gp130 that is essential for
STAT3 activation. EMBO J. 15: 1557-1565.

Yasukawa, K., T. Saito, K. Futatsugi, T. Saito, Y. Sekimori, Y. Koishihara, H. Fukui, Y. Ohsugi, T. Matsuda, H. Yawata, T. Hirano, T. Taga, and T. Kishimoto. 1990. Purification and characterization of soluble human IL-6 receptor expressed in CHO cells. J. Biochem. 108: 673-676.

Yin, T. and Y.-C. Yang. 1994. Mitogen-activated protein kinases and ribosomal S6 protein kinases are involved in signaling pathways shared by interleukin-11, interleukin-6, leukemia inhibitory factor, and oncostatin M in mouse 3T 3-L1 cells. J. Biol. Chem. 269: 3731-3738.

Yoshida, K., I. Chambers, J. Nichols, A. Smith, M. Saito, K. Yasukawa, M. Shoyab, T. Taga, and T. Kishimoto. 1994. Maintenance of the pluripotential phenotype of embryonic stem cells through direct activation of gp130 signalling pathways. Mech. Dev. 45: 163-171.

Yoshida, K., T. Taga, M. Saito, S. Suematsu, A. Kumanogoh, T. Tanaka, H. Fujiwara, M. Hirata, T. Yamagami, T. N akahata, T. Hirabayashi, Y. Yoneda, K. Tanaka, W.-Z. Wang, C. M ori, K. Shiota, N. Yoshida, and T. Kishimoto. 1996. Targeted disruption of gp130, a common signal transducer for the interleukin 6 family of cytokines, leads to myocardial and hematological disorders. Proc. Natl. Acad. Sci. 93: 407-411. 


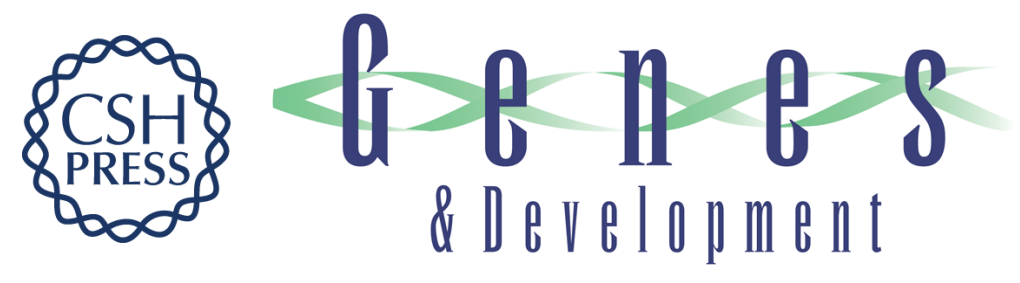

\section{Self-renewal of pluripotent embryonic stem cells is mediated via activation of STAT3}

Hitoshi Niwa, Tom Burdon, lan Chambers, et al.

Genes Dev. 1998, 12:

Access the most recent version at doi:10.1101/gad.12.13.2048

References This article cites 74 articles, 44 of which can be accessed free at: http://genesdev.cshlp.org/content/12/13/2048.full.html\#ref-list-1

License

Email Alerting

Receive free email alerts when new articles cite this article - sign up in the box at the top Service right corner of the article or click here.

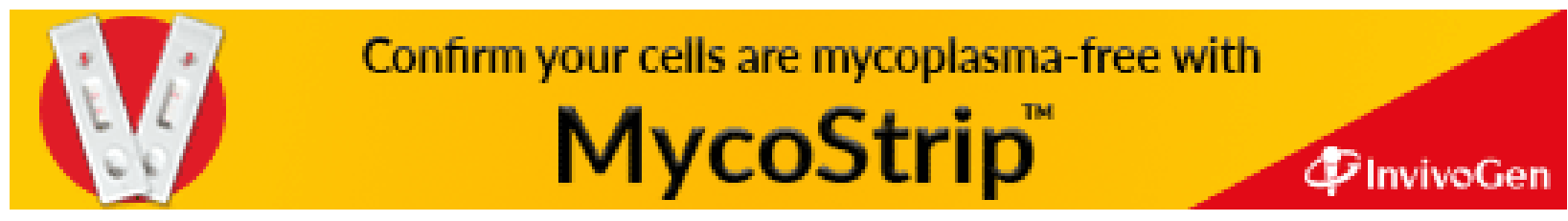

